(REVIEW ARTICLE)

\title{
Vegetable production and nematodes infestation: Impacts on small-scale farming communities of South Africa
}

\author{
Oso Adeola Abiola * \\ Department of Plant Science, Faculty of Agriculture and Natural Sciences, University of The Free State, Qwaqwa Campus, \\ Private Bag: x 13, Phuthaditjhaba 9866, Republic of South Africa.
}

Publication history: Received on 18 June 2020; revised on 06 August 2020; accepted on 09 August 2020

Article DOI: https://doi.org/10.30574/wjarr.2020.7.2.0211

\begin{abstract}
The South African agricultural sector is vital to the food and nutrition security of the population that is expected to increase from 54.4 million in 2019 to about 65.5 million by the year 2050. This increase in population emphasizes the need for a collaborative effort by all players in the agricultural value chain to ensure that natural resources are appropriately managed. Plant-parasitic nematodes are pests that threaten crop production worldwide, and root-knot nematodes (Meloidogyne species) are rated number-one due to their global occurrence, broad host range, and the damages inflicted in vegetable crops. The parasitism by Meloidogyne species delays crop maturity and reduces yield, which, together with poor quality of produce lead to escalating production costs, substantial income losses to farmers, and abandonment of community gardens. With the ban on synthetic fumigants, particularly methyl bromide, attention on management of this pest has generally shifted to the use of some ecologically-friendly approaches. The challenges of sufficiency and sustainability in vegetable production has become more intense with the rise in food demand of the increasing population, climate change, as well as biodiversity of complex pests associated with vegetable production. This review discusses vegetable production and its economic potentials in South Africa, damages to vegetable crops by the root-knot nematodes and their management, the outlook of smallholder farmers as well as identifies probable solutions toward the containment of nematode pest for food sufficiency and security in vegetable production in South Africa.
\end{abstract}

Keywords: Vegetables; Smallholders; Management; Meloidogyne incognita; Parasitism.

\section{Introduction}

\subsection{Vegetable production and economic potentials in South Africa}

Vegetable offers a unique market for South African farmers due to its nutritional importance as an essential requirement in a human's diet. South Africa is self-sufficient concerning vegetable production. About eighty-eight per cent of the output is sold through direct sales and also consumed by the smallholder farmers. Ten per cent is processed, while the remaining two per cent are exported [1]. Vegetable production is largely driven by a supply chain comprising of smallholder farmers to other multipliers in the value chain. The vegetable supply chain facilitates the expansion of domestic markets and is vital for job creation and food security. Vegetable production has been placed in the quadrant of having high growth potential in South African's economy [2]. The ranking of vegetables in the order of benefits accrue to the economy from their exporting potentials include butternut (43\%), carrots (19\%), potatoes (14\%), pumpkins $(13 \%)$ and onions (11\%) [3].

\subsection{Major indigenous vegetable crops of South Africa}

Indigenous vegetables are underutilized plants that have traditional uses and cultural links with the rural people and are sources of a great diversity of food, medicines, and other products. The vegetables are wrongly assumed to be food

\footnotetext{
${ }^{*}$ Corresponding author: Oso Adeola Abiola
}

Copyright (C) 2020 Author(s) retain the copyright of this article. This article is published under the terms of the Creative Commons Attribution Liscense 4.0. 
eaten by local people of 'indigenous' cultures and so not associated with the diet of Europeans, Asians, Americans. The stimuli for production, marketing, and consumption of these crops are the high costs of conventional exotic vegetables. The recent food and nutrition education has singled out indigenous vegetables for exceptional high nutritional quality and whose widespread consumption can prevent most non-communicable diseases. Unfortunately, the local and export markets are flooded by exotic crops, making it difficult for the introduction of indigenous crops, which remain largely a crop of small producers, mainly consumed in the areas of production [4]. The following are the most important indigenous vegetable in South Africa.

\subsubsection{Cleome}

(Cleome gynandra) (African cabbage, bangala or cleome) is grown mainly in KwaZulu-Natal, Free State, Northern Cape, Limpopo, and North-West Provinces. The tender leaves or young shoots, and often the flowers, are boiled in a stew or as a side dish. The leaves are somewhat bitter, and for this reason, are cooked with other leafy vegetables such as cowpea, amaranth and black nightshade [5].

\subsubsection{Amaranth}

(Amaranthus spp) (Amaranths, thepe, vowa, umfino) has the potential to improve nutrition, boost food security, foster rural development and support sustainable land care [6]. The main growing areas in South Africa are Limpopo, North West, Mpumalanga and KwaZulu-Natal [5]. The leaves are used as a vegetable in soups and stews; the grain contains $12-17 \%$ protein and is high in lysine, an amino acid deficient in other grain crops. The ground grain is used in bread, noodles, pancakes, cereals, granola, cookies and other flour-based products [4].

\subsubsection{Jews mallow}

(Corchorus olitorius L.) (Wild jute, thelele, delele, gushe) is used as a leafy vegetable. The immature fruit is dried and ground into a powder to prepare the sauce; dried leaves can be used as a thickener in soups. A tea is made from the dried leaves. It grows in the wild or at homesteads in the KwaZulu-Natal, Limpopo, Eastern Cape, and Mpumalanga provinces.

\subsubsection{Wild Watermelon}

(Citrullus lanatus) (Makataan, Karkoer, T'sama, Lerotse) are edible wild melons that tend to grow efficiently in large dry areas. Wild watermelon is majorly cultivated in Kgalagadi region of Northern Cape, Mpumalanga, Limpopo, KwaZuluNatal, Free State provinces [5]. The tender young leaves and fruit can be cooked and consumed like any other green vegetable. The seeds can also be dried, roasted and eaten or be ground into flour and cooked as porridge or baked into bread. Makataan seeds are extremely rich in antioxidant, vitamin C, minerals, fat, starch and riboflavin. The melon is used for jam, pickles, and preservatives.

\subsubsection{Blackjack}

(Bidens spinosa) (Gewane, Umhlabangubo, Uqadolo, Mushiji, Mokolonyane) widely harvested as a weed and cultivated in homestead gardens in the KwaZulu-Natal and Limpopo provinces [7]. Blackjack tender leaves and young stems are used as a leaf vegetable. The root, leaves and stem are reported to possess antiseptic and anti-inflammatory properties. Decoctions of powdered leaves are reported to be helpful in the treatment of arthritis, abdominal pains, headache, diarrhoea [8].

\subsection{Other vegetables of economic importance}

Several exotic plants have become so adapted and widely grown to satisfy the dietary needs of Europeans, Asians, and Americans. These are not indigenous plants because they do not have African origin and cannot be easily linked with wild species or close relatives.

\subsubsection{Tomato}

(Lycopersicon esculentus) is the second-largest traded vegetable on the five sizeable fresh produce markets in South Africa, after potatoes [9] constituting about 19\% gross value of the total vegetable production [10]. Limpopo is the major production area and followed by Mpumalanga, the Eastern Cape, and KwaZulu-Natal. Tomato contains a wide array of beneficial nutrients and antioxidants. It is also a source of vitamin $\mathrm{C}$ and choline, an essential nutrient that helps with sleep, muscle movement, learning and memory [10]. 


\subsubsection{Cabbage}

(Brassica oleracea) is one of the most cultivated brassica crops in South Africa, especially in the Eastern Cape Province [11]. Cabbage is $90 \%$ water and an excellent source of minerals, Vitamin A, and C and the B vitamins. It is used raw in salads, such as coleslaw, as a cooked vegetable, or preserved in pickles or sauerkraut [12].

\subsubsection{Beetroot}

(Beta vulgaris), commonly known as beet, is a biennial plant widely grown for its storage root in homesteads, commercial farms, and community gardens. The main production areas are situated in North-West, Gauteng, Mpumalanga, KwaZulu-Natal, and Western Cape provinces. Beetroot is a rich source of carbohydrates and protein and has high levels of essential vitamins, minerals, and micronutrients. The roots are eaten grilled, boiled, or roasted as a cooked vegetable or cold as a salad after cooking and adding oil and vinegar.

\subsubsection{Carrot}

(Daucus carota) is the fifth-largest traded vegetable on the five sizeable fresh produce markets [13] and one of the significant vegetables consumed in South Africa. Carrots can be eaten raw, whole, chopped, grated or added to salads for colour or texture. Carrot seed oil is used as a massage oil in creams and lotions. The entire plant can also be used as a fodder for cattle and horses.

\subsubsection{Cucurbits}

Cucurbits comprise several plant species commonly known as sweet melon, watermelon, baby marrow, pumpkin, squash, and cucumber.

\section{Watermelon}

Watermelon is one of the essential cucurbits widely grown throughout the world, and varieties that are frequently cultivated in South Africa are Charleston Grey, Sweet Princess, Crimson Sweet, and Congo. It has been used as a source of water, and for animal feed. Locally watermelon is planted in most warm areas of the country, Mpumalanga Lowveld, Limpopo, North West, and in some parts of the Eastern Cape.

\section{Pumpkin}

Pumpkin called pampoen by the Afrikaans; litsanga by SiSwati, ithanga by the isiZulu and fhuri by the Tshivenda of South Africa. Pumpkins are produced on a larger scale in the Mpumalanga Highveld and Lowveld, Vryburg in North West, Western Cape, and Vereeniging in Gauteng. Squash is mainly grown in the Mpumalanga Highveld, Mpumalanga Lowveld, and Gauteng (in the Vaal region). It is the most commonly and regularly grown among the cucurbits because it is a rich source of vitamin A, phosphorus and calcium. The young and tender shoots make tasty vegetable salads.

\section{Cucumbers}

Cucumbers are produced in almost all the provinces of South Africa but more concentrated in Western Cape, Eastern Cape, Free State, and KwaZulu Natal Provinces. In the recent past, the uptick in consumption of cucumber has significantly increased its production [2]. Cucumbers are high in potassium and fibre with moderate amounts of vitamins $\mathrm{A}$ and $\mathrm{C}$, as well as folic acid, phosphorus, and magnesium.

\subsubsection{Onions}

(Allium серa) are the third most important vegetable crop in South Africa, after potatoes and tomatoes [13]. They are mostly grown in the North-West, Limpopo, the Western Cape, and Northern Cape provinces. They are good sources of vitamin $\mathrm{C}$ and are essential for efficient uptake of iron. Onions are most often used to enhance flavour in a wide range of recipes, such as casseroles, pizzas, soups, and stews.

\subsubsection{Potato}

(Solanum tuberosum) is an important vegetable crop in South Africa, and the world's recognized staple food consumed by many people [14]. The bulk of potatoes is grown in Limpopo, the Western Free State, the Sandveld (Western Cape), and the Eastern Free State. Potatoes are fat and cholesterol-free and high in fibre. Potato starch is used as a thickener, binder of soups and sauces; elsewhere as an adhesive and for the manufacturing of papers and boards. In addition to being eaten as a vegetable by humans, potatoes can be used as feed for livestock. 


\section{Root-knot nematode pests of vegetables in South Africa}

Vegetables are indispensable in human diets for the nutritional benefits, and their production on smallholder and commercial farms improves the farmers' livelihoods [15]. Many crops grown as vegetables are susceptible to plantparasitic nematodes, particularly tomato, aubergine, cucumber, melon, carrot, gourds, lettuce, and peppers. In South Africa, the estimated $14 \%$ annual loss in agricultural and horticultural crops due to plant-parasitic nematodes had a value of over R1.9 billion [16]. The most important group of these nematodes, root-knot nematodes (Meloidogyne species) is also reported to be the dangerous pests of many vegetable crops, particularly in South African subsistence farming systems [17]. Out of the 22 identified species of Meloidogyne species in Africa, four most important and predominant root-knot nematodes posing a threat to crop production in South Africa are M. javanica, M. hapla, M. incognita and $M$. arenaria are regarded as $[18,19]$. Other reported important species include M. enterolobii, $M$. exigua and M. paranaensis [20], M. acronea, M. ethiopica, M. graminicola, M. hispanica, M. kikuyensis, M. partityla and M. vandervegtei $[18,21]$ and $M$. chitwoodi, M. fallax and M. naasi [20].

\section{Root-knot damage on vegetables}

The ability of root-knot nematodes to produce high numbers of offspring, particularly in warmer areas where they go through several life cycles in one season, is a major contributing factor to the high crop losses caused by these parasitic organisms [22]. The infective second-stage juveniles (J2) readily invade and rapidly multiply in the potato field at the onset of tuber initiation. Observable symptoms of root-knot infected potato plants are stunted growth, yellow foliage, premature wilting and die-back [23]. In tomato fields, the symptoms on above-ground infected plants usually include stunting, chlorosis and wilting. Feeding in the roots by root knots nematode often results in the formation of galls, also known as knots, which hinder nutrients and water uptake by the roots. Yield losses of 20-40\% [24] and over 50\% [25] caused by the infection of Meloidogyne spp have been reported on tomato. In cases of severe root-knot nematode infections, the whole root systems appear visible as thickened structures due to excessive galling [23]. Symptoms of root-knot damage on beetroot appear as galled areas on the tap and secondary roots, and at incidences of high infection levels, tubers appear deformed [23]. Although, research on the effects of root-knot nematodes on South African indigenous vegetables such as amaranth (Amaranthus spp.), spider flower (Cleome spp.), blackjack (Bidens spp) and nightshade (Solanum spp) is limited. Species of Solanum (S. retroflexum (wonder berry) and Amaranthus accessions, such as Arusha, Joseph's Coat, Bosbok Thepe, ex Botswana, and Applebosch, were reported highly susceptible to M. incognita and M. javanica [26].

\section{Management strategies}

The root-knot nematode management among farmers consists of chemical, cultural and biological control methods applied singly or in combination to achieve the desired results.

\subsection{Chemical control}

South Africa (SA) is one of the four largest importers of pesticides in sub-Saharan Africa, with more than 500 registered pesticides [27]. The smallholdings farmers are still prevalent in the rural areas of SA. Without the necessary awareness and training on pest management, farming households predominantly rely on the use of synthetic pesticides [28]. The use of nematicides to limit the build-up of nematode pest population densities below a damage threshold is, in general, effective. Still, the adverse environmental and human health effects cannot be ignored. The largest market for nematicides in South Africa is hinged on potato production. The market exists because of the extended period of invasion in potato roots and tubers, which necessitate nematicides application as pre-planting, planting, or postplanting measures. In tomato, the efficacy of both pre- and post-plant fenamiphos (a.s. $400 \mathrm{~g} / \mathrm{l}$ ) treatments in reducing a mixed population of $M$. javaniva and $M$. incognita has been documented by Daiber [29]. In the pea field, evaluation of dichloropropene, ethylene bromide, and fenamiphos at reduced rates against Meloidogyne sp and Pratylenchus penetrans infecting pea resulted in an increased in the growth of the plant as well as a 100\% yield [23]. The nematicides currently registered for use in pea are ethoprophos and fenamiphos [30]. For the management of root-knot nematode in beetroot, no nematicide has been registered in South Africa [30]. On pepper also, the only registered nematicide is Furfural [30].

\subsection{Cultural control}

Cultural control is one of the oldest and most economical methods with a principle based on the manipulation of the soil environment to reduce root-knot nematodes population. These practices include: 


\subsubsection{Resistant cultivars}

The use of resistant vegetable cultivar is one of the most feasible environmental friendly options for managing plantparasitic nematodes [31]. Resistance is species-specific; hence, the success of this method largely depends on target species of vegetables and nematodes. There have been documented reports of identified resistance of some genotypes of Amaranthus spp., beetroot, cabbage, dry bean [32], chilli, carrot, cowpea [33], green bean, pumpkin, maize [34], spinach and tomato $[6,33,35]$ to $M$. incognita and M. javanica.

\subsubsection{Organic amendment}

An organic amendment is any material of plant or animal origin that is added to the soil to improve its physical properties, including water retention, permeability, water infiltration, drainage, aeration, and structure. Incorporation of organic matter into the soil not only improves soil structure and moisture retention, but it also encourages biological control of the nematodes, in a cooperative research effort conducted in some parts of South Africa on the use of organic amendments for nematode management [17, 36, 37]. They investigated the effect of animal manures, compost and marigold amendments, as well as solarization on root-knot nematode population densities. Reductions in the population densities of root-knot nematodes at varying degrees were recorded among all the amended treatments.

\subsection{Biological control}

Biological control involves the use of living organisms either alive or inactive form against root-knot nematodes in plants. Paecilomyces lilacinus an egg parasitic fungi has been proven to control root-knot nematodes successfully, $M$. javanica and $M$. incognita on tomato, eggplant and other vegetable crops [38,39]. Goswami and Tiwari [40] reported that three Aspergillus species showed high toxicity against $M$. incognita juveniles. Trichoderma viride was similarly reported to reduce egg hatching [38]. Rhizosphere microorganisms such as Arbuscular mycorrhizal fungi (AMF) have also been reported to provide a front line defense for root pathogen attack [41]. These rhizosphere microorganisms have also been shown to reduce root-knot nematode population densities on tomato and other crops [42]. The two most studied parasitic bacteria are Pasteuria penetrans and Pseudomonas fluorescens. Amer-Zareen et al. [43] reported that Pasteuria penetrans effectively parasitized $M$. incognita in rotations. However, its efficacy depended on cropping techniques and soil conditions. Pseudomonas fluorescens was also reported to provide effective control of root-knot nematodes on vegetable crops [44].

\subsection{Botanical pesticides}

Higher plant species possess phytochemical compounds antagonistic to root-knot nematodes. These phytochemical compounds consisting alkaloids, alkamides, carbohydrates, cyanogenic glycosides, fatty acids, glucosinolates, nonprotein amino acids, phenolic compounds, polyacetylenes, polyketides, terpenoids, thiophenes, and waxes are reported to possess a broad spectrum mode of action [45, 46, and 47]. These plant species not only control nematodes but also improve soil health for optimal crop yield. The different botanical products and their application include:

\subsubsection{Botanical applied as extracts}

The nematicidal effects of extracts from tobacco (Nicotiana tabacum L), neem (Azadirachta indica), clove (Syzygium aromaticum L), Sunn hemp (Crotalaria spp.) and sweet flag (Acorus calamus L) have been reported on root-knot nematodes [48, 49]. Aqueous extract from leaves of Datura stramonium has been reported to inhibit juvenile survival and hatching of M. incognita [50]. Shoot extracts of Euphorbia helioscopia, Descurainia sophia, Gypsophila pilosa, Eruca sativa and Plantago lanceolata are reported to suppress root galls in tomato and also increased the fruit yield [51]. Extracts obtained from nematode-antagonistic plants like marigolds (Tagetes spp.), rattlepod (Crotalaria spectabilis), chrysanthemums (Chrysanthemum spp.), castor bean (Ricinus communis), margosa (Azadirachta indica), velvet bean (Mucuna deeringiana), Jack-bean (Canavalia ensiformis) and Abruzzi rye (Secale cereale) using a wide range of solvent polarities have been reported to possess a remarkable capacity to either paralyze or to kill nematodes inside plant tissue and in the surrounding soil, thus reducing population density [52,53]. The paring of suckers and subsequent dipping in red acalypha (Acalypha wilkesiana) plant extracts have been reported to have the potential for nematode control and promote a healthy rooting system for better plant development and crop yield [54]. In another trial, aqueous seed extracts of Canavalia ensiformis (L.) (Fabaceae), Crotalaria juncea (L.) (Fabacea), Crotalaria paulina (L.) (Fabaceae), Crotalaria spectabilis (L.) (Fabaceae), Tagetes minuta (L.) (Asteraceae), and Mucuna pruriens (L.) (Fabaceae) were screened for molecules active toward the infective stage (J2) of M. incognita. The aqueous crude extract of Canavalia ensiformis was reported with the highest nematicidal activity against M. incognita [55]. 


\subsubsection{Botanical applied as oil}

Oil-based formulations from plants have been reported to be effective against $M$. incognita in vegetables. Nafiesh Katooli et al. [56] reported that Chinaberry and Castor bean oil immobilized the juveniles of $M$. incognita, reduced nematode population in the soil, and also increased the longitudinal growth of cucumber plants. Also, essential oils and other secondary metabolites extracts from Asteraceae plant species have been reported to have direct effects on root-knot nematode egg hatchability and juvenile stage development $[57,58]$. Clove oil has demonstrated toxicity to plantparasitic nematodes [59]. In an experiment to evaluate the effect of the essential oil on mortality and egg hatching of second-stage juveniles of root-knot nematode in vitro studies and to resolve the effects of essential oil as root dip treatment in the management of $M$. incognita infecting tomato. Five commercially available essential oils used for the study included Citronella (Cymbopogon nardus), Eucalyptus (Eucalyptus globulus), Lemongrass (Cymbopogon citratus), Palmarosa (Cymbopogon martini) and Patchouli (Pogostemon cablin). Among the tested essential oils, C. citratus was the most effective, followed by C. martini and C. nardus [60].

\subsubsection{Botanical applied as a soil amendment}

The milled parts of these plants applied as amendments were also reported to reduce root galling and total population of nematodes in the soil [61]. Dry neem leaves incorporated into the soil reduced root-knot nematode, and significantly enhanced the weight of fruits in eggplants (Khan et al. 2012a). Studies using Canavalia ensiformis seed powder as a soil additive have been reported to a dramatically reduced number of eggs of M. incognita and M. javanica [63]. In a trial on the evaluation of the synergistic effect of neem and poultry manure on root-knot nematode (Meloidogyne spp.) infecting rice. Auwal et al. [64] reported that the combination of neem and poultry manure suppressed root-knot nematode population in the soil and that reduction in nematodes population was concomitant to increase in rice growth and yield parameters. A toxic effect of bitter leaf powder (Vernonia amygdalina) was evaluated against root-knot nematode (Meloidogyne incognita) infecting tomato (Solanum lycopersicum). It was reported that $V$. amygdalina leaves incorporated into the root-knot endemic soil suppressed population build-up of nematode, reduced root gall index and improved growth and yield of tomato [65].

\section{Smallholder farmers' outlook}

Smallholder farmers play an essential role in modern economies. In South Africa, the population of smallholder farmers is reported as 250,000 [66]. As smallholder producers, these farmers ensure that food supply is available within households, thereby stifling the effect of food prices on these households while improving food security. Smallholding farming is a sure way out of poverty and environmental hazards. It ensures that many people are engaged, and there is a less negative impact on the environment. However, smallholder farmers contend with other large value-chain participants in an ever-growing and increasingly complex environment. Documented challenges being faced by these smallholder farmers in South Africa include inadequate access to productive resources, prices of inputs such as fertilizers and pesticides, climate variability, information about markets and affordable transportation [67]. Vegetables attract a wide range of pests and diseases and as such, require intensive management. M. incognita was reported as a severe problem among the vegetable farming communities of South Africa $[17,68]$. Even though this nematode could be efficiently controlled, the majority of the smallholder farmers were not aware of its pestiferous potentials $[17,22]$. The community gardens were often abandoned because the farmers lacked sufficient financial power to purchase chemicals.

\section{Conclusion}

It has been shown that higher economic growth will be achieved in South Africa when the smallholder farmers are allowed space in the mainstream agricultural economy. Empowering smallholder farmers with agrarian skills to manage their natural resource base sustainably will resolve both economic and human development challenges bedevilling the country. Apart from problems associated with the integration of smallholder farmers into the mainstream, there are considerable challenges in the way these farmers react to pest problems on their farms. Pests and disease problems, exacerbated by farmers' poor perception of pest status, often result in reduced crop yields, and abandonment of gardens with consequences of threats to household and national food security. Therefore, increased accessibility to knowledge about these pests and diseases, particularly root-knot nematodes and their attendant negative implications are especially important. Efforts made to pass information to farmers on information days, field and farmers' days, farm field school, all add up to make productive contributions to the agricultural economy. However, one of the critical issues that need more attention is that these farming communities do not have sufficient financial resources. The economic power is required to access inputs such as high-yielding, domesticated or commercial crop varieties, ecologically safe solutions for resilience to nematode pest amongst others. From a general perspective, several 
stages of interconnected integration, pieces of training and financial support would play a significant role in the containment of nematode pest for food sufficiency and security in vegetable production in South Africa. However, the future lies in investing in the generation of knowledge and technologies that will provide policymakers with necessary insights for better planning and policy development aimed at sustainable agricultural production.

\section{Compliance with ethical standards}

\section{Acknowledgments}

The author acknowledges The University of the Free State, South Africa for the support provided through access to bibliographic databases and Ekiti State University, Ado-Ekiti, Nigeria for granting the postdoctoral leave.

\section{Disclosure of conflict of interest}

The author has declared that no conflict of interest exists.

\section{References}

[1] APAP. (2015). Agricultural Policy Action Plan, 38.

[2] Sihlobo W. (2018). A Few Notes on South Africa's Banana Market.

[3] FPEP. (2019). Fresh Produce Exporters' Report.

[4] DAFF. (2010). Cabbage. Department of Agriculture Forestry and Fisheries, Pretoria.

[5] DAFF. (2013). Most common indigenous food crops of South Africa. Department of Agriculture, Forestry and Fisheries, Pretoria, 28.

[6] Steyn WP, Daneel MS and Slabbert MM. (2013). Evaluation of Amaranthus species for their host suitability to the root-knot nematodes, Meloidogyne incognita race 2 and Meloidogyne javanica in South Africa Acta horticulturae, 1007, 403-407.

[7] DAFF. (2011). Garden peas (Pisium sativum) production. Department of Agriculture, Forestry and Fisheries, Pretoria.

[8] Faber M, Oelofse A, Van Jaarsveld PJ, Wenhold FAM and Jansen Van Rensburg WS. (2010). African Leafy vegetables consumed by household in the Limpopo and KwaZulu-Natal. S Afr J Clin Nutr, 23, 30-38.

[9] DAFF. (2017). A profile of the South African tomato market value chain, 42.

[10] DAFF. (2014). A profile of South African tomato market chain. Department of Agriculture, Forestry and Fisheries, Pretoria.

[11] Kiribige D. (2014). A comparison of estimated maize and cabbage enterprise budgets of ideal small-scale commercial and subsistence farms in the Eastern Cape Province of South Africa. International Journal of Economics, Commerce and Management, 12, 1-14.

[12] DAFF. (2018). A profile of the South African cabbage market value chain. Department of Agriculture, Forestry and Fisheries, Pretoria.

[13] ABSA. (2017). Agri-business Market Analysis.

[14] DAFF. (2012). A profile of South African cucumber market chain. Department of Agriculture, Forestry and Fisheries, Pretoria.

[15] Ngegba MP, Sesay M and Bangura ET. (2016). The impact of vegetable farming on the livelihood of small-scale farmers in Koinadugu district Northern Sierra Leone. Global Journal of Bio-science and Biotechnology, 5, 42-49.

[16] ARC. (2011). Research on nematodes.

[17] Ntidi NK, Fourie H, Mc Donald AH, De Waele D and Mienie CMS. (2012). Plant-parasitic nematodes associated with weeds in developing agriculture in South Africa. Nematology, 14, 875-887.

[18] Onkendi EM, Kariuki GM, Marais M and Moleleki LN. (2014). The threat of root-knot nematodes (Meloidogyne spp.) in Africa. A review Plant Patholology, 63, 727-737. 
[19] Karuri HW, Olago D, Neilon R, Mararo E and Villinger J. (2017). A survey of root-knot nematodes and resistance to Meloidogyne incognita in sweet potato varieties from Kenyan fields. Crop Protection, 92,114-121.

[20] Karssen G, Wesemae WML and Moens M. (2013). Root-knot nematodes. In: Perry R.N, Moens, M. (eds) Plant nematology. CAB International, Wallingford, UK, 73-108.

[21] Kleynhans KPN, Van den Berg E, Swart A, Marais M and Buckley NH. (1996). Plant nematodes in South Africa Pretoria, South Africa: ARC-Plant Protection Research Institute: Plant Protection Research Institute Handbook, 8.

[22] Mashela PW, De Waele D, Fourie H, Dube Z and Khosa MC. (2017). Alternative nematode management strategies: In Fourie, H., Spaull, V.W., Jones, R.K., Daneel, MS, and De Waele, D, eds. Nematology in South Africa: a review from the $21^{\text {st }}$ century. Springer, 151-181.

[23] Jones RK, Storey SG, Knoetze R and Fourie H. (2017). Nematode pests of potato and other vegetable crops. In: Fourie H, Spaull VW, Jones RK, Daneel MS, De Waele D (eds) Nematology in South Africa: a view from the 21st century. Springer, Cham, Switzerland, 231-260.

[24] Bridge J and Starr JL. (2007). Plant nematodes of agricultural importance. Boston, MA, Academic Press.

[25] Nono-Womdim R, Swai IS, Mrosso LK, Chadha ML and Opefia RT. (2002). Identification of root-knot nematode species occurring on tomatoes in Tanzania and resistant lines for their control. Plant Disease, 86, 127-130.

[26] Farmer's weekly. (2019). Nematodes' negative impact on African leafy vegetables.

[27] PAN. (2010). PAN Pesticide database.

[28] Fourie H, Mc Donald AH, De Waele D and Jordaan A. (2013). Comparative cellular responses in resistant and susceptible soybean cultivars infected with Meloidogyne incognita. Nematology, 15, 695-708.

[29] Daiber KC. (1990c). Effect of fenamiphos on population dynamics of Meloidogyne incognita and M. javanica and on yield of tomatoes. Phytophylactica, 22, 307-310.

[30] Van Zyl K. (2013). A guide to crop pest management in South Africa. A compendium of acaricides, insecticides, nematicides, molluscicides, avicides, and rodenticides. A Crop Life South African Compendium. 1st ed. Pinetown: VR Print.

[31] Williamson VM and Roberts PA. (2009). Mechanisms and genetics of resistance. In: R. N. Perry, M. Moens, and J. L. Starr (Eds.) Root-knot Nematodes. Wallingford, UK: CAB International, 301-325.

[32] Mtshali M, Fourie H and Mc Donald AH. (2002). Host suitability of commercial South African dry bean cultivars to Meloidogyne javanica and M. incognita race 2 African Plant Protection, 8,14-15.

[33] Riekert HF. (1999). Screening of local cowpea cultivars and lines for resistance to Meloidogyne javanica. African Plant Protection, 5, 11.

[34] Ngobeni GL, Fourie H, Mc Donald AH and Mashela PW. (2011). Host suitability of selected South African maize genotypes to the root-knot nematode species Meloidogyne incognita race 2 and Meloidogyne javanicaSouth African Journal of Plant Soil, 28, 49-54.

[35] Mothata TS. (2006). Evaluation and verification of resistance in selected vegetable crops for sustainable rootknot nematode management in developing agriculture. MSc Dissertation, North-West University, Potchefstroom.

[36] Fourie H and Schoeman MJ. (1999). Nematode management in home gardens and small-scale farming systems: a preliminary study. African Plant Protection, 5, 12-13.

[37] Mtshali M, Fourie H and Mc Donald AH. (2002a). Incidence of root-knot nematodes in resource-poor agriculture in South Africa. African Plant Protection, 8, 88-89.

[38] Goswami BK and Mittal A. (2004). Management of root-knot nematode infecting tomato by Trichoderma viride and Paecilomyces lilacinus.Indian Phytopathology, 57, 235-236.

[39] Kumar V, Haseeb A and Sharma A. (2009). Integrated management of Meloidogyne incognita- Fusarium solani disease complex of brinjal cv. Pusa Kranti. Annals of Plant Protection Science, 17, 192- 194.

[40] Goswami J and Tiwari DD. (2007). Management of Meloidogyne incognita and Fusarium oxysporum f.sp lycopersici disease complex on tomato by Trichoderma harzianum, Tinospora longifolia and Glomus fasciculatum. Pesticide Research Journal, 19, 51-55. 
[41] Oyekanmi EO, Coyne DL, Fagade OE and Osonubi O. (2007). Improving root-knot nematode management of two soybean genotypes through the application of Bradyrhizobium japonicum, Trichoderma pseudokoningii and Glomus mosseae in full factorial combinations. Crop Protection, 26, 1006-1012.

[42] Shreenivasa KR, Krishnappa K, Ravichandra NG, Ravikumar B, Kirankumar KC and Karuna K. (2007). Optimization of Arbuscular mycorrhizal fungus, Glomus fasciculatum culture against root-knot nematode, Meloidogyne incognita on tomato. Asian Journal of Microbiology, Biotechnology and Environmental Sciences, 9, $117-121$.

[43] Amer-Zareen ZMJ, Abid M, Gowen SR and Kerry BR. (2004). Management of root-knot nematode (Meloidogyne javanica) by bio-control agents in two crop rotations. International Journal of Biology and Biotechnology, 1, 6773.

[44] Haseeb A and Kumar V. (2006). Management of Meloidogyne incognita-Fusarium solani disease complex in brinjal by biological control agents and organic additives. Annals Plant Protection Sciences, 887, 519-521.

[45] Chitwood DJ. (2002). Phytochemical based strategies for nematode control. Annual Review of Phytopathology, 40, 221-249.

[46] Okwute SK. (2012). Plants as potential sources of pesticidal agents. A review in: Soundararajan RP (ed) Pesticides: advances in chemical and botanical pesticides. Academic, Detroit.

[47] Wink M and Van Wyk BE. (2014). Medicinal Plants of the World. Briza Publications, Pretoria.

[48] Wiratno D, Taniwiryono H, Vann de Berg H, Riksen JAG, Rietjenu IMCM, Dijwanti SR, Kammenga JE and Murk AJ. (2009). Nematicidal activity of plant extracts against the Root-knot nematode, Meloidogyne incognita.The Open Natural Product Journal, 2, 77-85.

[49] Hildalgo-Diaz L and Kerry BR. (2007). Integration of biological control with other methods of nematode management. Nematodes, 2, 29-49.

[50] Sellami S and Mouffarrah A. (1994). Effect of some aqueous plant extracts on juvenile hatching and larval mortality against M. incognita. Mededelingrn Faculteit- Landbouwkundige-en- Toegepaste-Biologi scheWetensch appen, Universiteit - Gent, 59, 813-816.

[51] Hoseinpoor R and Kargar A. (2012). Evaluation of the effect powder and aqueous extracts of some plant species on tomato yield and reproduction of Meloidogyne incognita. International Journal of Agricultural Science, 2, 964 968.

[52] Ferraz S and Freitas LG. (2004). Use of antagonistic plants and natural products. In Z. X. Chen, S. Y. Chen, \& D. W. Dickson (Orgs.), Nematology: Advances and perspectives. Volume 2: Nematode management and utilization, 931-977.

[53] Sano Z. (2005). Cultural control of nematode damage. Large Encyclopedia of Environmental Conservation Agriculture. Noubunkyo, Tokyo, 281-316.

[54] Oso AA, Longe 00 and Olaniyi MO. (2016). Nematicidal effects of red acalypha (Acalypha wilkesiana) on plantain yield and corm damage by nematodes. International Journal of Agriculture and Environmental Research, 3, 549557.

[55] Rocha TL, Soll CB, Boughtonb BA, Silva TS, Oldach K, Firminoa AAP, Callahanh DL, Sheedyd J, Silveirae ER, Carneiroa RMDG, Silva LP, Poleza VLP, Bacic A, Grossi-de-Saa MF and Roessner U. (2017). Prospection and identification of nematoxic compounds from Canavalia ensiformis seeds effective in the control of the root-knot nematode Meloidogyne incognita. Biotechnology Research and innovation, 1, 87-100.

[56] Nafiseh KE, Mahdikhani MAT and Saeid N. (2010). Management of root-knot nematode on cucumber with the extract and oil of nematicidal plants. International Journal of Agricultural Research, 5, 582-586.

[57] Gong B, Bloszies S, Li X, Wei M, Yang F, Shi Q and Wang X. (2013). Efficacy of garlic straw application against rootknot nematodes on tomato. Scientia Horticulturae, 161, 49-57.

[58] Hooks CRR, Wang KH, Ploeg A and McSorley R. (2010). Using marigold (Tagetes spp.) as a cover crop to protect crops from plant-parasitic nematodes. Applied Soil Ecology, 46, 307-320.

[59] Meyer SLF, Lakshman LK, Zasada IA, Vinyard BT and Chitwood DJ. (2008). Phytotoxicity of clove oil to vegetable crop seedlings and nematotoxicity to root-knot nematodes. Hortechnology, 18, 631-638. 
[60] Patidar RK, Debashish S, Pathak M, Shakywar RC and Paridar RK. (2016). Effect of essential oils on mortality, hatching, and multiplication of root-knot nematode, Meloidogyne incognita and its impact on plant growth parameters. International Journal of Agriculture, Environment and Biotechnology, 885-895.

[61] Akpheokhai IL, Cole AOC and Fawole B. (2012). Evaluation of some plant extracts for the management of Meloidogyne incognita on soybean (Glycine max). World Journal of Agricultural Science, 8, 429-435.

[62] Khan MR, Mohiddin FA, Ejaz MN and Khan MM. (2012). Management of root-knot disease in eggplant through the application of bio-control fungi and dry neem leaves. Turkish Journal of Biology, 36, 161-169.

[63] Lopez EA, Ferraz S, Dhingra OD, Ferreira PA and Freitas LG. (2009). Soil amendment with castor bean oilcake and jack bean seed powder to control Meloidogyne javanica on tomato roots. Nematologia Brasileira, 33, 106-109.

[64] Auwal HM, Galadima IB, Madu J and Joseph P. (2015). Evaluation of synergistic effect of neem and poultry manure on root-knot nematode (Meloidogyne spp.) infecting rice. Open Access Library Journal, 2e1372.

[65] Abolusoro SA, Izuogu NB, Abolusoro PF, Ige SA and Adebiyi OTV. (2018). Toxic effects of bitter leaf powdered (Vernonia amygdalina) Del, on root-knot nematode (Meloidogyne incognita), affecting tomato (Lycopersicon esculentum). Journal of Advanced Plant Science, 1, 211.

[66] Aliber M and Hill R. (2012). Support for smallholder farmers in South Africa: Challenges of scale and strategy. Development South Africa, 29, 548-562.

[67] Mpandeli S and Maponya P. (2014). Constraints and challenges facing small-scale farmers in Limpopo Province, South Africa. Journal of Agricultural Science, 6, 135-143.

[68] Fourie H, Mc Donald AH, Mothata TS, Ntidi KN and De Waele D. (2012). Indications of variation in host suitability to root-knot nematode populations in commercial tomato varieties. African Journal of Agricultural Research, 7, 2344-2352. 